\title{
Relationship between Stalk and Cob Mechanical Strength during the Late Growth Stage of Maize (Zea mays L.)
}

\author{
Jun Xue ${ }^{1}$, Qun Wang ${ }^{1}$, Hongyan Li ${ }^{1}$, Yinghu Fan ${ }^{2}$, Lulu Li ${ }^{1}{ }^{10}$, Ruizhi Xie ${ }^{1}$, Keru Wang ${ }^{1}$, \\ Bo Ming ${ }^{1}$ (D), Peng Hou ${ }^{1}$ and Shaokun Li ${ }^{1, *}$ \\ 1 Institute of Crop Sciences, Chinese Academy of Agricultural Sciences, Key Laboratory of Crop Physiology \\ and Ecology, Ministry of Agriculture, Beijing 100081, China; xuejun5519@126.com (J.X.); \\ wangquns1@163.com (Q.W.); Lhy200_1@163.com (H.L.); lilulu19910818@163.com (L.L.); \\ xieruizhi@caas.cn (R.X.); wangkeru@caas.cn (K.W.); mingbo@caas.cn (B.M.); houpeng@caas.cn (P.H.) \\ 2 Chuxiong Academy of Agricultural Sciences in Yunnan, Chuxiong 675000, China; 13038699285@163.com \\ * Correspondence: lishaokun@caas.cn; Tel.: +86-10-82108891
}

Received: 30 August 2020; Accepted: 14 October 2020; Published: 17 October 2020

\begin{abstract}
The stalk strength of maize (Zea mays L.) has a significant effect on stalk lodging and harvesting loss, and the cob mechanical strength affects the grain broken rate in mechanical grain harvesting. Clarifying the relationship between maize stalk strength and cob mechanical strength could provide a theoretical basis for the selection of cultivars with high lodging resistance and high suitability for mechanical grain harvesting. In 2017 and 2018, 64 maize cultivars were planted in four locations to investigate the changes in the bending strength of stalks and cobs using the three-point bending method during the late growth stage. The results showed that, in the late growth stage, with increasing number of days after physiological maturity, the stalk bending strength (SBS) of the fifth internode above the soil gradually decreased, the cob bending strength (CBS) decreased first and then increased, and it was lowest at about six to eight days after physiological maturity. In the same experimental site and sampling period, there was no significant correlation between the SBS and the CBS of different maize cultivars. Cluster analysis showed that most of the investigated maize cultivars showed low stalk strength during the late growth stage. However, a few of the maize cultivars were suitable for mechanical grain harvesting due to their characteristics of high stalk bending strength and moderate cob bending strength during the late growth stage.
\end{abstract}

Keywords: maize (Zea mays L.); stalk; cob; mechanical strength; cultivar

\section{Introduction}

Mechanical grain harvesting is the development direction of maize production in China [1]. The mechanical harvesting of maize requires kernel moisture contents lower than $27 \%$ [2,3]. Kernel dehydration via plant standing in the field after physiological maturity is an important measure to reduce kernel moisture content [4]. After maize physiological maturity, the plant height, ear height, internode length, and internode diameter does not change. However, the decomposition of carbohydrate and the decrease of moisture content causes the stalk mechanical strength to decrease, which increases the risk of lodging during the late growth stage of maize [5,6]. Maize lodging decreases the grain yield by approximately 5-50\% [7-9]. In addition to grain loss, lodging increases harvest costs and reduces grain quality. The ear loss has been found to increase by $0.15-0.59 \%$ for each one percent increase in lodging rate [10]. Therefore, maintaining high stalk strength during the late growth stage is important for ensuring in-field kernel dehydration in order to facilitate mechanical grain harvesting. 
A high kernel breakage rate is the main impediment to the mechanical harvesting of maize in China [11]. The cob characteristics have an important effect on the kernel breakage rate [12]. For instance, maize cultivars with high cob hardness easily break into several segments in the harvester drum during mechanical grain harvesting. In mechanical threshing, due to the impact of the broken cob on the kernels, the kernel breakage rate increases [13]. Maize kernels with a high moisture content have lower hardness [14]. Therefore, the kernel moisture content is the most important factor affecting the kernel breakage rate for kernels with a high moisture content [15]. When the kernel moisture content is reduced to a certain level, the kernel elasticity is reduced, and the resistance to impact is therefore also reduced $[16,17]$. It has been found that the kernel breakage rate increases as the cob mechanical strength increases [18]. Therefore, appropriate cob hardness is beneficial to reducing the kernel breakage rate during the late growth stage of maize.

The ideal maize cultivars for mechanical grain harvesting should have high stalk mechanical strength and moderate cob mechanical strength. It is true that the lateral branches (the "shanks") are developed from axillary buds of the main stalk. However, the cob shares a developmental pathway more similar to tassel development since they are both floral structures that have similar meristematic structures. Therefore, it is not clear that the cob would share anything in common with the stalk. The relationship between cob mechanical strength and stalk mechanical strength is not clear. It is also unclear whether maize cultivars with a high stalk mechanical strength and lodging resistance also have high cob mechanical strength in current production.

Three-point bending tests were often employed in selective breeding studies to characterize stalk mechanical strength [19]. Three-point bending tests provide several advantages as compared with other testing methods, including ease of specimen preparation, ease of test setup, and minimal post processing of data [20]. Therefore, bending tests were used to investigate crop lodging [21,22], correlations between density and strength $[23,24]$. Three-point bending tests include node-loaded and internode-loaded. The internode-loaded three-point bending test method significantly underestimates actual stalk bending strength, while node-loaded three-point bending tests are likely to provide improved phenotyping accuracy in selective breeding studies seeking to increase stalk strength and lodging resistance [20]. In addition, Robertson et al. [20] suggested maximizing the span length to minimize the transverse load. However, the stalk short-span strength, which was measured using Stalk Strength Tester (YYD-1; Hangzhou TOP Instrument, China), was significantly correlated to lodging rate in field [25]. In this study, considering that the maize cob has no node and the cob was short, the stalk short-span bending strength (SBS) and cob short-span bending strength (CBS) were measured as the mechanical strength of stalk and cob. Different modern maize cultivars were planted at multiple experimental sites in different years in spring and summer maize regions. Differences in the SBS and CBS were investigated in different growth stages to analyze the relationship between these two parameters in different maize cultivars. The results provide a theoretical basis for breeding and screening maize cultivars that are suitable for mechanical grain harvesting.

\section{Materials and Methods}

\subsection{Experimental Design}

Field experiments were conducted during the 2017 and 2018 maize growing seasons at Xinxiang Experimental Station, Chinese Academy of Agricultural Sciences, Henan Province ( $35^{\circ} 18^{\prime} \mathrm{N}, 113^{\circ} 54^{\prime}$ E), Qitai Farm, Xinjiang Province ( $43^{\circ} 50^{\prime}$ N, $89^{\circ} 46^{\prime}$ E), Yinchuan test base of the Ningxia Academy of Agriculture and Forestry Sciences, Ningxia Province ( $\left.38^{\circ} 15^{\prime} \mathrm{N}, 106^{\circ} 15^{\prime} \mathrm{E}\right)$, and the Beijing Experimental Station, Chinese Academy of Agricultural Sciences, Beijing ( $\left.38^{\circ} 58^{\prime} \mathrm{N}, 116^{\circ} 20^{\prime} \mathrm{E}\right)$. The maize season and hybrids used for each site are shown in Table 1.

In Xinxiang, the planting density was $6.75 \times 10^{4}$ plants ha $^{-1}$ in 2017 and $7.5 \times 10^{4}$ plants ha $^{-1}$ in 2018, and the sowing dates were 18 June and 13 June in 2017 and 2018, respectively. The dates of 
physiological maturity ranged from 15 October to 27 October in both years. In both years, each plot contained a total of $1025-\mathrm{m}$-long rows with a $60-\mathrm{cm}$ row spacing.

In Qitai, the planting density was $10.5 \times 10^{4}$ plants ha $^{-1}$. Plants were seeded in alternating wide-narrow row patterns (row widths of 70 and $40 \mathrm{~cm}$ ). The sowing date was 20 April, 2018, and the dates of physiological maturity ranged from 20 August to 10 October. The area of each plot was $300 \mathrm{~m}^{2}$.

In Yinchuan, the planting density was $9.0 \times 10^{4}$ plants ha $^{-1}$. The sowing date was 08 April, 2018. The dates of physiological maturity ranged from 20 August to 10 October. The area of each plot was $72 \mathrm{~m}^{2}$ and the row spacing was $60 \mathrm{~cm}$.

In Beijing, the planting density was $7.5 \times 10^{4}$ plants ha ${ }^{-1}$. The sowing date was 7 June 2018. The dates of physiological maturity ranged from 20 September to 10 October. The area of each plot was $48 \mathrm{~m}^{2}$ and the row spacing was $60 \mathrm{~cm}$.

In the four experimental sites, all cultivars were arranged in randomized complete blocks. Each cultivar was replicated three times. Field water and fertilizer management were conducted according to local farmer management. Pesticides were applied as needed to control insect populations, and weeds were periodically removed by hand.

Table 1. Maize hybrids grown in different experimental sites in 2017 and 2018.

\begin{tabular}{|c|c|c|c|c|}
\hline Year & Maize Season & Experimental Site & $\begin{array}{l}\text { Number of } \\
\text { Cultivars }\end{array}$ & Cultivars \\
\hline 2017 & Summer maize & Xinxiang, Henan & 28 & $\begin{array}{l}\text { Liaodan } 585 \text { (LD585), Liaodan } 586 \\
\text { (LD586), Liaodan 575 (LD575), MC670, } \\
\text { Zeyu 501 (ZY501), Zeyu 8911 (ZY8911), } \\
\text { Jidan66 (JD66), Dongdan } 913 \text { (DD913), } \\
\text { Yufeng 303 (YF303), Zhongkeyu 505 } \\
\text { (ZKY505), Lianchuang 808 (LC808), } \\
\text { Lianchuang 825 (LC825), Jintong 152 } \\
\text { (JT152), Nonghua } 5 \text { (NH5), Nonghua } 816 \\
\text { (NH816), Hengyu 898 (HY898), Dika } 517 \\
\text { (DK517), Dika 653 (DK653), Xindan } 58 \\
\text { (XD58), Xindan } 65 \text { (XD65), Xindan } 68 \\
\text { (XD68), Shandan } 636 \text { (SD636), Shandan } \\
\text { 650 (SD650), Yuyu } 30 \text { (YY30), Lidan 295 } \\
\text { (LD295), LA505, Beidou 309 (BD309), } \\
\text { Yudan 9953 (YD9953) }\end{array}$ \\
\hline \multirow[t]{4}{*}{2018} & Summer maize & Xinxiang, Henan & 8 & $\begin{array}{c}\text { Fengken } 139 \text { (FK139), JNK728, ZD958, } \\
\text { DK517, DK653, Hetian } 1 \text { (HT1), ZY8911, } \\
\text { Xianyu } 335 \text { (XY335) }\end{array}$ \\
\hline & Summer maize & Beijing & 9 & $\begin{array}{c}\text { JD66, JNK728, DK517, FK139, XY335, } \\
\text { LC825, ZD958, LD295, ZY8911 }\end{array}$ \\
\hline & Spring maize & Qitai, Xinjiang & 23 & $\begin{array}{c}\text { MC278, KWS2030, KX9384, ZP191, } \\
\text { BD309, Bixin 101 (BX101), Denghai 105 } \\
\text { (DH105), Denghai 177 (DH177), Denghai } \\
\text { 1888 (DH1888), Denghai 515 (DH515), } \\
\text { Denghai 551 (DH551), DD913, Jidan 588 } \\
\text { (JD588), Jiuyu M03 (JYM03), LD575, } \\
\text { Ningdan13 (ND13), Nonghua 106 } \\
\text { (NH106), Shandan 620 (SD620), SD650, } \\
\text { Youqi 909 (YQ909), ZY8911, Zhenjin } 308 \\
\text { (ZJ308), Zhengtai 101 (ZT101) }\end{array}$ \\
\hline & Spring maize & Yinchuan, Ningxia & 25 & $\begin{array}{c}\text { Denghai } 786 \text { (DH786), KX9384, Huamei } 1 \\
\text { (HM1), Yinyu 274 (YY274), Yinyu } 439 \\
\text { (YY439), Denghai 769 (DH769), JD66, } \\
\text { Nonghua } 213 \text { (NH213), LD295, LD575, } \\
\text { SD620, Dongdan (DD1331), Fuyou } \\
\text { (FY968), LC825, DK517, LD585, XY335, } \\
\text { DK519, SD650, ZD958, M751, Demeiya 1 } \\
\text { (DMY1), Jiushenghe (JSH692), Xinyu } 47 \\
\text { (XY47), Zengyu (ZY1572) }\end{array}$ \\
\hline
\end{tabular}




\subsection{Sampling and Measurements}

(1) Sampling Date

In the late growth stage of maize, the short-span bending strength of the fifth internode above the soil and the short-span bending strength of the cob were measured on different dates. The sampling dates are shown in Table 2.

Table 2. The measurement dates of stalk and cob short-span bending strength in different experimental sites in both experimental years.

\begin{tabular}{|c|c|c|c|}
\hline \multirow{2}{*}{ Year } & \multirow{2}{*}{ Experimental Site } & \multicolumn{2}{|c|}{ Measurement Date } \\
\hline & & Stalk Bending Strength & Cob Bending Strength \\
\hline 2017 & Xinxiang, Henan & $\begin{array}{c}21 \text { October, } 1 \text { November, } 10 \\
\text { November, } 21 \text { November, } 22 \text { Dec }\end{array}$ & $\begin{array}{c}6 \text { October, } 16 \text { October, } 27 \text { October, } 10 \\
\text { November, } 25 \text { November }\end{array}$ \\
\hline 2018 & $\begin{array}{l}\text { Xinxiang, Henan } \\
\text { Beijing } \\
\text { Qitai, Xinjiang } \\
\text { Yinchuan, Ningxia }\end{array}$ & $\begin{array}{r}16 \text { September, } 23 \text { September, } 30 \text { Sept } \\
10 \mathrm{~N} \\
8 \text { Octobe } \\
8 \text { October, } 17\end{array}$ & $\begin{array}{l}\text { ber, } 7 \text { October, } 14 \text { October, } 27 \text { October } \\
\text { ember } \\
17 \text { October } \\
\text { ober, } 27 \text { October }\end{array}$ \\
\hline
\end{tabular}

\section{(2) Stalk Short-Span Bending Strength}

Five maize plants were randomly selected from each plot. The stalk short-span bending strength of the fifth elongation internode above the soil was determined via three-point bending tests conducted using a stalk strength tester according to the methods of Kamran et al. [25]. The stalk strength tester was comprised of a supporting structure made from two grooved plates, a force gauge with a digital display screen, and a U-shaped probe (Figure 1a). Before measuring the stalk short-span bending strength, the grooved plates were adjusted at $8-\mathrm{cm}$ intervals. The internode was laid horizontally on the grooved plates and the distance between the force gauge and internode was adjusted. Then, the U-shaped probe was vertically aligned with the internode and slowly pressed downwards until the internode was broken. The maximum value of the applied force $(\mathrm{N}=$ Newton; displayed on the display screen) was taken as the short-span bending strength. All measurements were made in the middle of each internode at its widest side (Figure 1b).

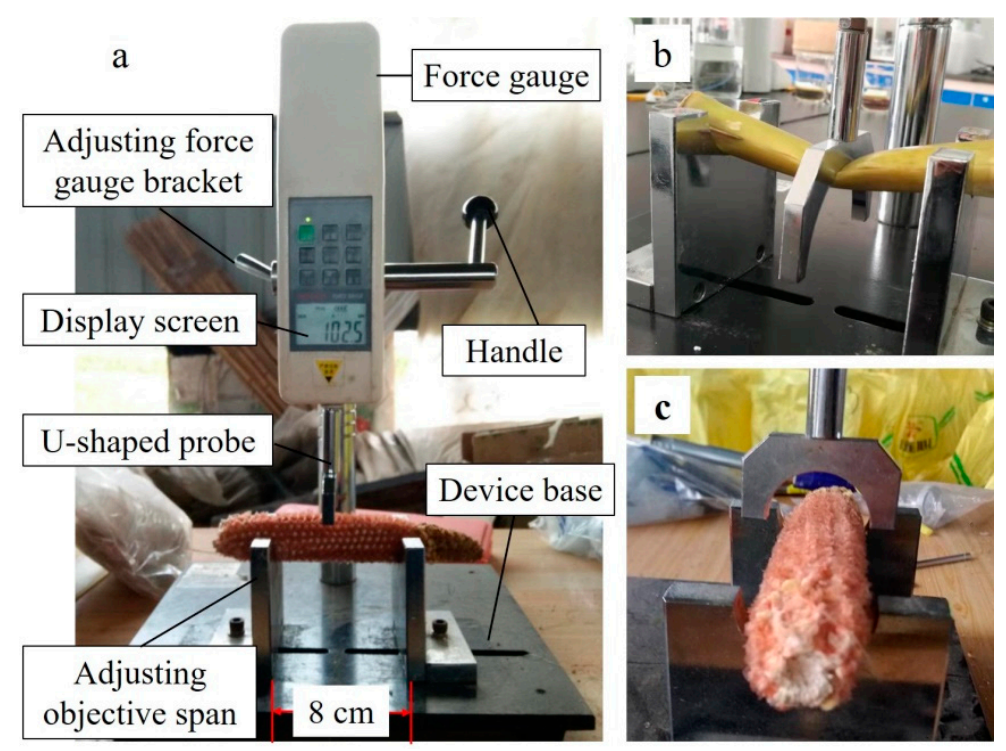

Figure 1. Stalk strength tester used in this study. (a) is the supporting structure, force gauge, and " $U$ "-shaped probe; (b) is the measuring of stalk bending strength; (c) is the measuring of cob bending strength.

(3) Cob Short-Span Bending Strength 
Five maize ears were randomly selected from each plot. Maize kernels were removed by hand. The cob was laid horizontally on the grooved plates at 8-cm intervals. Then, the U-shaped probe was vertically aligned with the cob and slowly pressed downwards until the cob was broken. All measurements were taken at the middle of the cob. For the Qitai experimental sites in 2017 and all experimental sites in 2018, the internode and cob were from the same plant (Figure 1c).

\section{(4) Stalk Lodging Rate}

In the Xinxiang and Yinchuan experimental sites, stalk lodging naturally occurred in the late growth stage. The number of lodged plants were recorded in the middle four rows of each plot along a length of $10 \mathrm{~m}$ at the same time as the samples were acquired for the measurement of stalk short-span bending strength. Plants were considered to be stalk-lodged when they were broken at or below the ear-bearing node. The stalk lodging rate was calculated by dividing the number of lodged plants from the total number of plants in the investigation area.

\subsection{Statistical Analyses}

Statistical analyses were performed using the Predictive Analytics Software (PASW) version 18.0 (IBM SPSS, Somers, NY, USA). Data from each sampling date were analyzed separately. Means were tested using least significant difference tests at the $p<0.05$ level (LSD 0.05) for datasets with three or more groups. Pearson correlations were calculated to determine the relationships between stalk and cob short-span bending strength. The maize cultivars in Xinxiang, Qitai, and Yinchuan were classified into six categories using systematic cluster analysis based on the stalk short-span bending strength and cob short-span bending strength at harvesting. The operation steps in PASW are analyze, classify, and hierarchical cluster. The cluster method was between-group linkage. The measure interval was square Euclidean distance. The dendrogram was drawn by PASW [26].

\section{Results}

\subsection{Stalk Short-Span Bending Strength}

As shown in Figure 2, during the late growth stage of maize, the stalk short-span bending strength (SBS) of the fifth internode above the soil gradually decreased with increasing number of days after physiological maturity; SBS was linearly and negatively correlated with the number of days after physiological maturity. In 2017, the average SBS of the 28 cultivars in the Xinxiang site decreased from 190.6 to $131.9 \mathrm{~N}$ during the test period. In 2018, the average SBS decreased from 181.4 to $124.6 \mathrm{~N}$ in the Xinxiang site, from 139.2 to $120.5 \mathrm{~N}$ in the Qitai site, and from 186.2 to $132.3 \mathrm{~N}$ in the Yinchuan site. For the same growth season, experimental site, and measurement period, the SBS varied among the tested maize cultivars. 

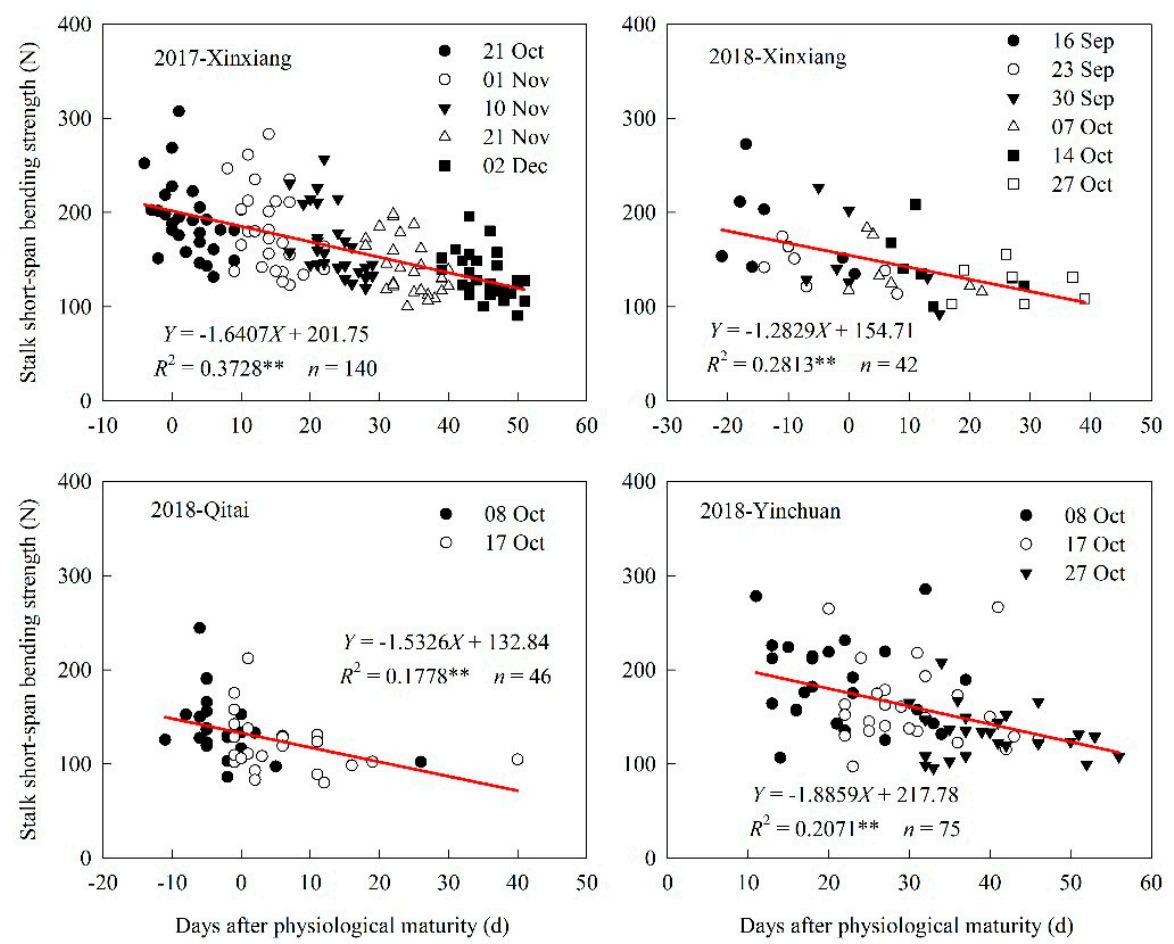

Figure 2. Changes in stalk short-span bending strength during the late growth stage. Same symbol presents the stalk short-span bending strength in different cultivars at the same sampling date. ${ }^{* *}$ significant at the 0.01 level.

As shown in Figure 3, during the late growth stage, the stalk lodging rate increased as the SBS decreased. In the Xinxiang experimental site, the fitting equation of summer maize was $Y=(1746.52 / X)$ -6.55 , where $Y$ is the stalk lodging rate and $X$ is the SBS, while in the Yinchuan experimental site, the fitting equation of spring maize was $Y=-0.0705 X+18.539$. According to the equations, when the stalk bending strength was lower than $151.2 \mathrm{~N}$ in Xinxiang and lower than $192.0 \mathrm{~N}$ in Yinchuan, the stalk lodging rate was higher than the Chinese national standard for mechanical grain harvesting (lodging rate $<5 \%$ ).
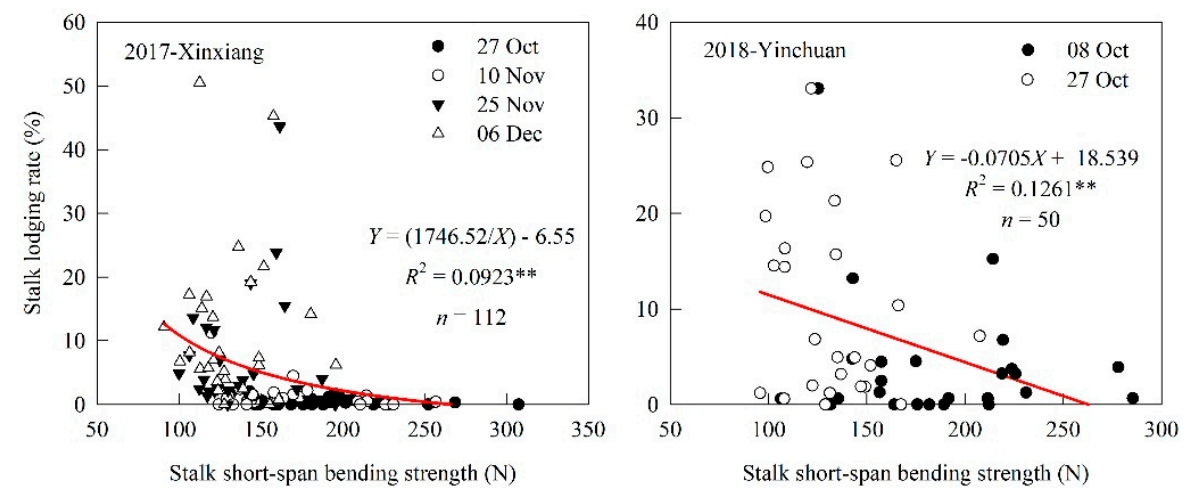

Figure 3. Relationship between stalk short-span bending strength and stalk lodging rate during the late growth stage. ${ }^{* *}$ Significant at the 0.01 level. Same symbol presents the relationship between stalk short-span bending strength and stalk lodging rate in different maize cultivars at the same sampling date.

\subsection{Cob Short-Span Bending Strength}

In the Xinxiang experimental site, during the late growth stage of maize, the cob short-span bending strength (CBS) first decreased and then increased with increasing number of days after 
physiological maturity (Figure 4). On the quadratic curve, which was fitted between CBS and days after physiological maturity, the CBS was lowest at $6 \mathrm{~d}$ after physiological maturity in 2017 and at $8 \mathrm{~d}$ after physiological maturity in 2018. Due to the late determination in Qitai and Yinchuan, the CBS gradually increased in the late growth stage in these locations. In the same growth season, experimental site, and measurement period, the CBS differed among the tested maize cultivars.
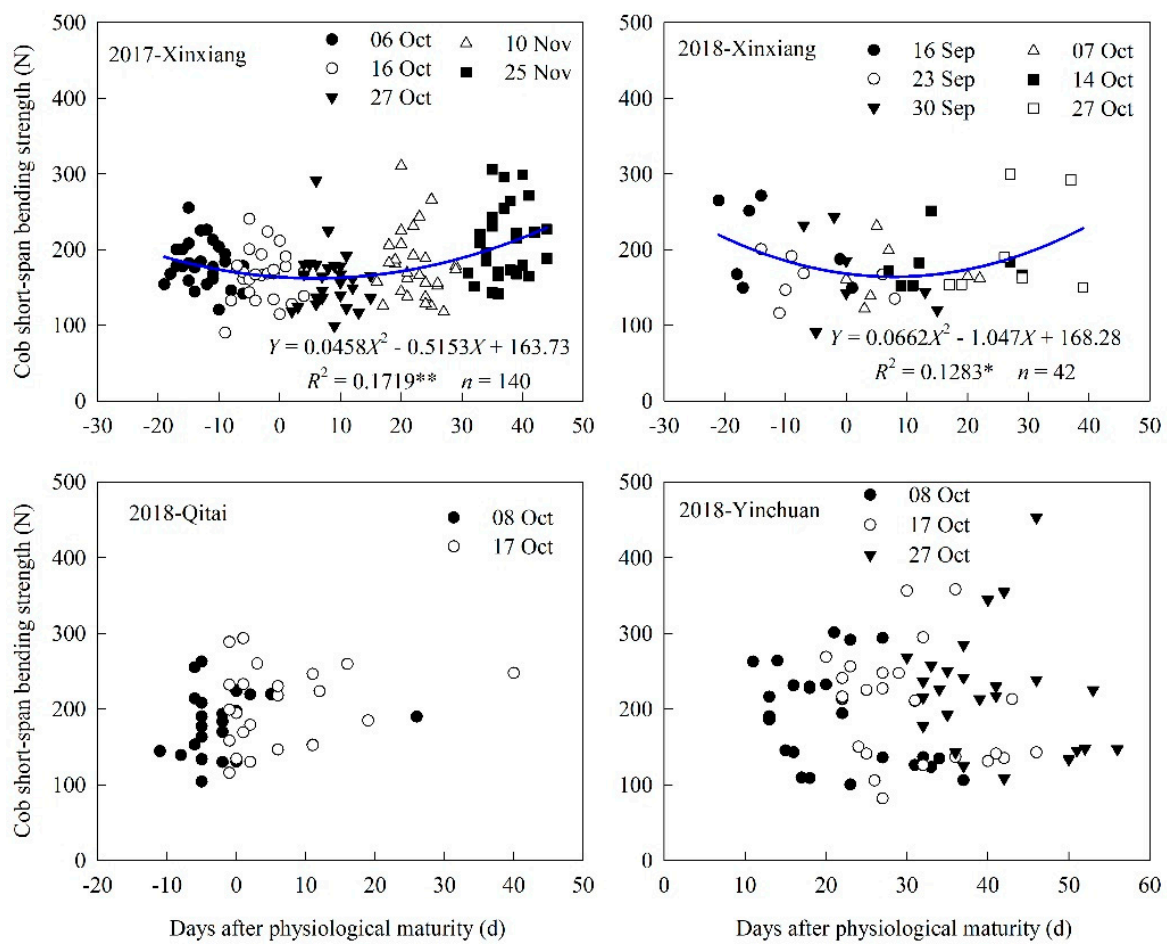

Figure 4. Changes in cob short-span bending strength during the late growth stage. Same symbol presents the cob short-span bending strength in different cultivars at the same sampling date * Significant at the 0.05 level, ** significant at the 0.01 level.

\subsection{Relationship between Stalk and Cob Short-Span Bending Strength}

The results of the correlation analysis of the relationship between SBS and CBS for different sampling dates showed that in the Xinxiang experimental site of 2017, the CBS on 16 October was significantly negatively correlated with the SBS on 21 October (Table 3). There was no significant correlation between CBS and SBS on other sampling dates. In the Xinxiang (Table 4), Qitai (Table 5), Yinchuan (Table 6), and Beijing $(r=-0.189, n=9)$ experimental sites of 2018, the CBS was not significantly correlated with the SBS on any sampling dates. These results indicate that there is no correlation between the CBS and the SBS during the late growth stage in the studied maize cultivars.

Table 3. Results of the correlation analysis between stalk short-span bending strength and cob short-span bending strength in Xinxiang of $2017(n=28)$.

\begin{tabular}{cccccccc}
\hline & \multicolumn{6}{c}{ Stalk Short-Span Bending Strength } \\
\cline { 3 - 8 } & & $\begin{array}{c}\mathbf{2 1} \\
\text { October }\end{array}$ & $\begin{array}{c}\mathbf{0 1} \\
\text { November }\end{array}$ & $\begin{array}{c}\mathbf{1 0} \\
\text { November }\end{array}$ & $\begin{array}{c}\mathbf{2 1} \\
\text { November }\end{array}$ & 02 Dec & \multirow{2}{*}{ 12 Dec } \\
\hline \multirow{3}{*}{$\begin{array}{c}\text { Cob short-span } \\
\text { bending strength }\end{array}$} & 16 October & $-0.390^{*}$ & -0.266 & -0.228 & -0.112 & -0.063 & -0.017 \\
& 28 October & -0.287 & -0.173 & -0.175 & -0.240 & -0.221 & -0.198 \\
& 10 November & -0.114 & 0.009 & 0.072 & -0.017 & -0.050 & -0.078 \\
& 25 November & -0.372 & -0.285 & -0.168 & -0.242 & -0.324 & -0.298 \\
\hline
\end{tabular}

* represents significant difference at the $p<0.05$ level. 
Table 4. Results of the correlation analysis between stalk short-span bending strength and cob short-span bending strength in Xinxiang of $2018(n=7)$.

\begin{tabular}{cccccccc}
\hline & \multicolumn{5}{c}{ Stalk Short-Span Bending Strength } \\
\cline { 3 - 7 } & & $\begin{array}{c}\mathbf{1 6} \\
\text { September }\end{array}$ & $\begin{array}{c}\mathbf{2 3} \\
\text { September }\end{array}$ & $\begin{array}{c}\mathbf{3 0} \\
\text { September }\end{array}$ & 7 October & $\mathbf{1 4}$ & $\mathbf{2 7}$ \\
October & October \\
\hline \multirow{5}{*}{ Cob short-span } & 16 September & -0.31 & -0.248 & -0.358 & -0.499 & -0.338 & -0.194 \\
bending strength & 23 September & -0.411 & -0.238 & -0.478 & -0.614 & 0.01 & -0.446 \\
& 30 September & -0.352 & -0.172 & -0.403 & -0.508 & 0.007 & -0.384 \\
& 7 October & -0.479 & -0.424 & -0.565 & -0.583 & 0.474 & -0.148 \\
& 14 October & -0.114 & -0.587 & -0.466 & -0.498 & -0.666 & 0.002 \\
& 27 October & -0.306 & 0.12 & -0.105 & -0.178 & -0.075 & 0.251 \\
\hline
\end{tabular}

Table 5. Results of the correlation analysis between stalk short-span bending strength and cob short-span bending strength in Qitai of $2018(n=23)$.

\begin{tabular}{cccc}
\hline \multirow{2}{*}{} & & \multicolumn{2}{c}{ Stalk Short-Span Bending Strength } \\
\cline { 3 - 4 } & & 8 October & 17 October \\
\hline Cob short-span & 8 October & 0.161 & 0.142 \\
bending strength & 17 October & 0.153 & 0.144 \\
\hline
\end{tabular}

Table 6. Results of the correlation analysis between stalk short-span bending strength and cob short-span bending strength in Yinchuan of $2018(n=25)$.

\begin{tabular}{ccccc}
\hline & & \multicolumn{2}{c}{ Stalk Short-Span Bending Strength } \\
\cline { 3 - 5 } & & 8 October & 17 October & 27 October \\
\hline \multirow{2}{*}{ Cob short-span } & 8 October & 0.015 & -0.030 & -0.047 \\
bending strength & 17 October & 0.014 & -0.056 & 0.001 \\
& 27 October & -0.030 & -0.068 & 0.149 \\
\hline
\end{tabular}

An analysis of 25 plant samples for the same maize cultivar and sampling period showed that the CBS was significantly positively correlated with the SBS in four maize cultivars in Xinxiang and two cultivars in Beijing (Figure 5). Based on the coefficient of determination $\left(\mathrm{R}^{2}\right)$ of the fitting equation, cultivar Jingnongke (JNK728) was found to have the strongest correlation between CBS and SBS (Table 7). Additionally, the slope of the fitting equation showed that the largest change in CBS with SBS occurred for this cultivar. In contrast, cultivar Zhengdan 958 (ZD958) had the lowest coefficient of determination and lowest slope of the fitting equation.
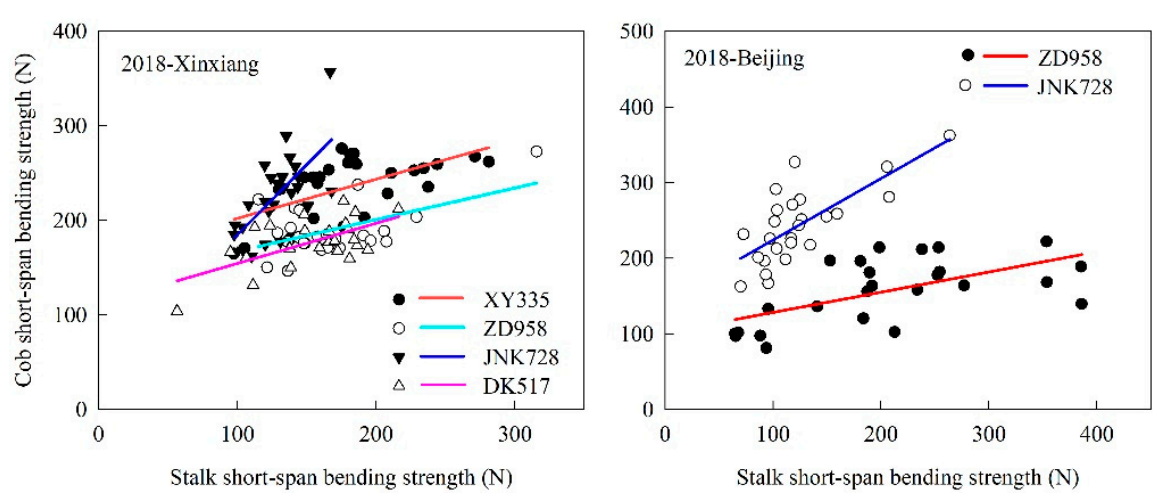

Figure 5. Relationship between stalk short-span bending strength and cob short-span bending strength for maize cultivars Xianyu 335 (XY335), Zhengdan 958 (ZD958), Jingnongke 728 (JNK728), and Dika (DK517). Same symbol presents the relationship between stalk short-span bending strength and cob short-span bending strength for the same maize cultivar. 
Table 7. Fitting equations between the stalk short-span bending strength $(X)$ and the cob short-span bending strength $(Y)$ for different samples of same maize cultivar.

\begin{tabular}{cccc}
\hline Experimental Site & Cultivar & Equation & $\boldsymbol{R}^{\mathbf{2}}$ \\
\hline Xinxiang & XY335 & $Y=0.4138 X+160.7$ & $0.3581^{* *}$ \\
& ZD958 & $Y=0.3347 X+133.82$ & $0.2735^{* *}$ \\
& JNK728 & $Y=1.4855 X+36.067$ & $0.4381^{* *}$ \\
DK517 & $Y=0.4248 X+111.97$ & $0.3775^{* *}$ \\
\multirow{2}{*}{ Beijing } & ZD958 & $Y=0.2671 X+101.59$ & $0.3661^{* *}$ \\
& JNK728 & $Y=0.8127 X+142.71$ & $0.5346^{* *}$ \\
\hline
\end{tabular}

** Significant at the 0.01 level.

\subsection{Classification of Maize Cultivars}

Based on the data of SBS and CBS at harvest for Xinxiang in 2017 and Qitai and Yinchuan in 2018, the maize cultivars were classified into four categories using cluster analysis (Figure 6). The results are shown in Table 8. In Xinxiang in 2017, cultivars Zhongkeyu (ZKY505) and Xindan (XD65) had the highest SBS and moderate CBS. In 2018, the maize cultivars with the highest SBS and moderate CBS were Jiuyu M03 (JYM03) in Qitai and Yinyu 274 (YY439) in Yinchuan. Most maize cultivars were the I, II, and III types with low SBS.
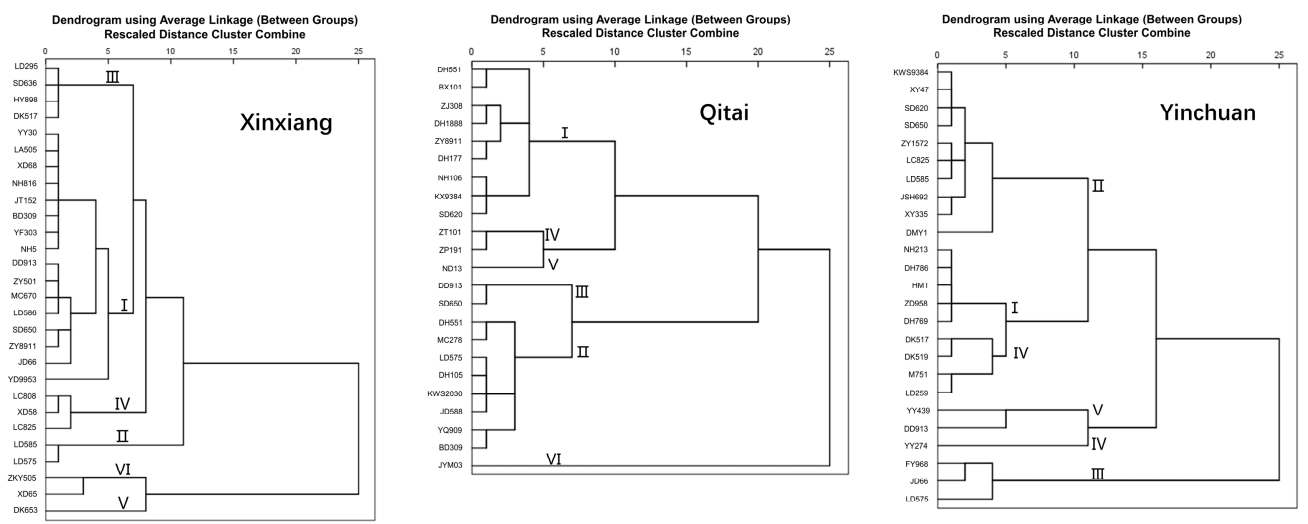

Figure 6. Cluster analysis of different maize cultivars based on the stalk short-span bending strength and cob short-span bending strength at harvesting. 
Table 8. Cluster analysis of different maize cultivars based on the stalk and cob bending strength.

\begin{tabular}{|c|c|c|c|c|c|c|}
\hline Year & $\begin{array}{l}\text { Experimental Site } \\
\text { and Date }\end{array}$ & Classification & Cultivar & Number of Cultivars & $\begin{array}{c}\text { Average Stalk } \\
\text { Short-Span Bending } \\
\text { Strength }(\mathbf{N})\end{array}$ & $\begin{array}{c}\text { Average Cob } \\
\text { Short-Span Bending } \\
\text { Strength (N) }\end{array}$ \\
\hline \multirow[t]{6}{*}{2017} & \multirow[t]{6}{*}{$\begin{array}{l}\text { Xinxiang } \\
(n=28) \\
16 \text { October }\end{array}$} & I & $\begin{array}{l}\text { LD586, JD66, DD913, YD9953, } \\
\text { ZY501, MC670, SD650, ZY8911, } \\
\text { JT152, XD68, YY30, LA505, } \\
\text { NH816, BD309, YF303, NH5, }\end{array}$ & 16 & 167.3 & 173.2 \\
\hline & & II & LD585, LD575 & 2 & 189.8 & 232.0 \\
\hline & & III & HY898, DK517, LD295, SD636 & 4 & 195.4 & 127.4 \\
\hline & & IV & LC808, XD58, LC825 & 3 & 223.0 & 179.6 \\
\hline & & $\mathrm{V}$ & DK653 & 1 & 252.3 & 90.0 \\
\hline & & VI & ZKY505, XD65 & 2 & 288.0 & 138.0 \\
\hline \multirow[t]{12}{*}{2018} & \multirow{6}{*}{$\begin{array}{c}\text { Qitai } \\
(n=23) \\
17 \text { October }\end{array}$} & I & $\begin{array}{c}\text { ZY8911, ZJ308, DH1888, DH177, } \\
\text { DH515, BX101, NH106, KX9384, } \\
\text { SD620 }\end{array}$ & 9 & 105.8 & 151.6 \\
\hline & & II & $\begin{array}{l}\text { YQ909, LD575, BD309, JD588, } \\
\text { KWS2030, DH105, DH551, } \\
\text { MC278 }\end{array}$ & 8 & 108.3 & 239.6 \\
\hline & & III & DD913, SD650 & 2 & 133.0 & 291.0 \\
\hline & & IV & ZT101, ZP191, & 2 & 149.9 & 196.7 \\
\hline & & $\mathrm{V}$ & ND13 & 1 & 175.3 & 158.2 \\
\hline & & VI & JYM03 & 1 & 212.1 & 232.9 \\
\hline & \multirow{6}{*}{$\begin{array}{l}\text { Yinchuan } \\
(n=25) \\
17 \text { October }\end{array}$} & I & $\begin{array}{l}\text { HM1, NH213, DH786, ZD958, } \\
\text { DH769, } \\
\text { KWS9384 XY47 SD620 SD650 }\end{array}$ & 5 & 129.7 & 137.2 \\
\hline & & II & $\begin{array}{c}\text { LD585, LC825, ZY1572, JSH692, } \\
\text { XY335, DMY1, }\end{array}$ & 10 & 143.0 & 229.8 \\
\hline & & III & LD575, FY968, JD66 & 3 & 153.1 & 336.3 \\
\hline & & IV & LD295, M751, DK517, DK519, & 4 & 185.7 & 115.8 \\
\hline & & $\mathrm{V}$ & DD1331, YY439 & 2 & 241.2 & 240.0 \\
\hline & & VI & YY274 & 1 & 266.4 & 141.1 \\
\hline
\end{tabular}




\section{Discussion}

The application and promotion of mechanical grain harvesting technology is still in its infancy in China. Maize cultivars with high stalk mechanical strength and strong lodging resistance during the late growth stage is a future breeding direction [11]. Carbohydrate and water are the material basis for the mechanical strength of maize stalk. During the late growth stage of maize, the plant's ability to absorb water and nutrients is reduced due to rapid root senescence, while the transpiration and photosynthetic capacity are significantly reduced due to leaf senescence, and carbon partitioning and carbon movement from source tissues to the developing ear. These changes cause the carbohydrate and water content of stalks to reduce, which in turn leads to cell atrophy, cell wall degradation and thinning, cell gap increase, and the consequent decrease of stalk toughness and stalk mechanical strength. Maize stalk breakage mostly occurs between the second and fifth internodes above the soil [5]. The present study showed that, during the late growth stage, with increasing number of days after physiological maturity, the stalk short-span bending strength of the fifth internode above the soil decreased and the stalk lodging rate increased. When the stalk short-span bending strength was lower than $151.2 \mathrm{~N}$ in Xinxiang and lower than $192.0 \mathrm{~N}$ in Yinchuan, the stalk lodging rate was higher than the Chinese national standard for mechanical kernel harvesting (lodging rate $<5 \%$ ). Therefore, the decrease of stalk mechanical strength is an important factor that increases the risk of stalk lodging during the late growth stage of maize.

The mechanical strength of maize cob is an important factor in the kernel breakage rate during mechanical harvesting. This study found that, during the late growth stage, the cob short-span bending strength first reduced and then increased with increasing number of days after physiological maturity. This is similar to the findings of previous studies. For example, Anazodo [27] reported that during the late stage of maize growth, the cob mechanical strength first decreased and then increased with increasing number of days after physiological maturity, and the cob bending strength and elastic modulus was significantly different among different maize cultivars. Before physiological maturity, carbohydrate is transported from the cob to grains [28], which reduces the cob carbohydrate content and thus decreases the cob mechanical strength. In the present study, it was found that the cob mechanical strength was the lowest six to eight days after physiological maturity. However, the stalk short-span bending strength decreased with decreasing stalk water content. This may be due to the high proportion of pith tissue in the stalk, which is prone to rot when the stalk activity is reduced during the late growth stage.

Maize stalk and cob have similar structures, both containing a hard rind and soft pith. Maize breeds are selected based on stalk dry matter accumulation and mechanical strength [29-31]. However, less attention is paid to the mechanical properties of the cob. As such, it is unclear whether maize cultivars with a high stalk mechanical strength also have high cob mechanical strength. In this study, the stalk and cob short-span bending strength were found to vary widely among the investigated maize cultivars. Furthermore, the stalk and cob short-span bending strength were found to vary between planting areas for the same maize cultivar. In Xinxiang in 2017, the cob short-span bending strength on 16 October was found to be significantly correlated with the stalk bending strength on 21 October. However, no significant correlation was observed between stalk short-span bending strength and cob short-span bending strength for other sampling dates and planting regions. Nevertheless, a significant positive correlation was observed between the stalk short-span bending strength and cob short-span bending strength for different samples of the same cultivar; the correlation coefficient was highest for JNK728 and lowest for ZD958.

During the maize filling stage, Beck et al. [32] found a competitive relationship between stalk and ear sinks. Other studies reported that the removal of the ear at flowering increased the stalk quality. Maize plants with a single ear had higher stalk mechanical strength than those with double ears [33]. When maize is near physiological maturity, the filling rate decreases, and carbohydrates accumulate in the stalk. Therefore, maize cultivars with a longer leaf stay-green period have high carbohydrate accumulation [34-36] and high stalk mechanical strength. In contrast, maize cultivars 
with a longer leaf stay-green period had higher cob moisture content and consequently lower cob mechanical strength [34]. Therefore, the mechanical strength of stalks and cobs may be negatively correlated during the late growth stage in different maize cultivars.

The results of cluster analysis showed that 78.6, 82.6, and 72.0\% of maize cultivars in Xinxiang, Qitai, and Yinchuan, respectively, were classified into types I, II, and III with low stalk short-span bending strength. Meanwhile, 75.0, 52.2, and $40.0 \%$ of maize cultivars in Xinxiang, Qitai, and Yinchuan, respectively, had low cob mechanical strength. In types IV, V, and VI with low stalk short-span bending strength, the maize cultivars ZKY505, XD65, JYM03, and YY439 had moderate cob short-span bending strength. This indicated that the investigated maize cultivars have characteristics that are conducive to field standing and grain dehydration. Further analysis showed that the parents of these cultivars were based on foreign cultivars, especially US cultivars. Guo et al. [37] concluded that European maize genes should be introduced in the Huang-Huai-Hai planting region of China, and that the heterotic combination pattern of US maize genes $\times$ European maize genes may create maize cultivars with high resistance to lodging and high yield which are suitable for mechanical grain harvesting.

Maize lodging can occur at both the stalk and the root. This study only analyzed and categorized maize cultivars based on stalk short-span bending strength that is closely related to stalk lodging during the late growth stage. In maize production, the selection of cultivars that are suitable for mechanical grain harvesting should be based on stalk lodging and root lodging characteristics. Additionally, cultivars with excessively soft cobs may have a high impurity rate during mechanical grain harvesting. This study only qualitatively analyzed the relationship between the mechanical strength of maize stalk and cob. Future studies should quantitatively investigate the mechanical strength of maize cob for suitable mechanical grain harvesting.

\section{Conclusions}

During the late growth stage of maize, stalk short-span bending strength (SBS) was found to gradually decrease with increasing number of days after physiological maturity. Meanwhile, the cob short-span bending strength (CBS) first decreased and then increased with increasing number of days after physiological maturity, with the lowest cob bending strength occurring at six to eight days after physiological maturity. No significant correlation was observed between SBS and CBS among different maize cultivars. A few maize cultivars were observed to possess characteristics that are conducive to stalk lodging resistance and mechanical grain harvesting. The maize cultivars that have high SBS and moderate CBS and that are suitable for mechanical grain harvesting can be selected through various breeding methods.

Author Contributions: Conceptualization, J.X. and S.L.; methodology, J.X. and S.L.; investigation, Q.W., J.X., H.L., Y.F., and L.L.; data analysis, J.X., R.X., K.W., B.M., P.H., and S.L.; writing-original draft preparation, J.X.; writing - review and editing, J.X., R.X., K.W., B.M., P.H., and S.L.; supervision, J.X. and S.L.; project administration, J.X. All authors have read and agreed to the published version of the manuscript.

Funding: This research was funded by National Key Research and Development Program of China, grant number 2018YFD0100206, the China Agriculture Research System (CARS-02-25), and the Agricultural Science and Technology Innovation Project of Chinese Academy of Agricultural Sciences.

Conflicts of Interest: The authors declare no conflict of interest.

\section{References}

1. Li, S.K.; Zhao, J.R.; Dong, S.T.; Zhao, M.; Li, C.H.; Cui, Y.H.; Liu, Y.H.; Gao, J.L.; Xue, J.Q.; Wang, L.C. Advances and prospects of maize cultivation in China. Sci. Agric. Sin. 2017, 50, 1941-1959.

2. Xie, R.; Lei, X.; Wang, K.; Guo, Y.; Chai, Z.; Hou, P.; Li, S. Research on corn mechanically harvesting grain quality in Huanghuaihai plain. Crops 2014, 36, 76-79.

3. Li, L.L.; Xie, R.Z.; Wang, K.R.; Ming, B.; Hou, P.; Li, S.K. Kernel moisture content of summer maize at physiological maturity stage in Huanghuaihai region. Crops 2017, 2, 88-92. 
4. $\quad$ Li, L.L.; Xue, J.; Xie, R.-Z.; Wang, K.-R.; Ming, B.; Hou, P.; Gao, S.; Li, S.-K. Effects of grain moisture content on mechanical grain harvesting quality of summer maize. Acta Agron. Sin. 2018, 44, 1747-1754. [CrossRef]

5. Xue, J.; Wang, Q.; Li, L.L.; Zhang, W.X.; Xie, R.Z.; Wang, K.R.; Ming, B.; Hou, P.; Li, S.K. Changes of maize lodging after physiological maturity and its influencing factors. Acta Agron. Sin. 2018, 44, 1747-1754. [CrossRef]

6. Wang, Q.; Xue, J.; Zhang, G.Q.; Chen, J.L.; Xie, R.Z.; Ming, B.; Hou, P.; Wang, K.R.; Li, S.K. Nitrogen split application can improve the stalk lodging resistance of maize planted at high density. Agriculture 2020, 10, 364. [CrossRef]

7. Zuber, M.S.; Kang, M.S. Corn lodging slowed by sturdier stalks. Crops Soils. 1978, 30, 13-15.

8. Minami, M.; Ujihara, A. Effects of lodging on dry matter production: Grain yield and nutritional composition at different growth stages in maize (Zea mays L.). Jpn. J. Crop Sci. 2008, 60, 107-115. [CrossRef]

9. Li, S.Y.; Ma, W.; Peng, J.Y.; Chen, Z.M. Study on yield loss of summer maize due to lodging at the big flare stage and grain filling stage. Sci. Agric. Sin. 2015, 19, 3952-3964.

10. Xue, J.; Li, L.L.; Xie, R.Z.; Wang, K.R.; Hou, P.; Ming, B.; Zhang, W.-X.; Zhang, G.-Q.; Gao, S.; Bai, S.-J. Effect of lodging on maize grain losing and harvest efficiency in mechanical grain harvest. Acta Agron. Sin. 2018, 44, 1774-1781. [CrossRef]

11. Li, S.K. Factors affecting the quality of maize grain mechanical harvest and the development trend of grain harvest technology. J. Shihezi Univ. (Nat. Sci.) 2017, 35, 265-272.

12. Wang, K.R.; Li, S.K. Progresses in research on grain broken rate by mechanical grain harvesting. Sci. Agric. Sin. 2017, 50, 2018-2026.

13. Sehgal, S.M.; Brown, W.L. Cob morphology and its relation to combine harvesting in maize. Iowa State J. Sci. 1965, 39, 251-268.

14. Guo, Y.; Xue, J.; Ming, B.; Hou, J.; Fan, Y.; Dong, P.; Wang, K.; Xie, R.; Hou, P.; Li, S. Kernel hardness of different maize cultivars and the relationship between kernel hardness and moisture content. J. Maize Sci. 2020, 28, 122-127.

15. Chai, Z.; Wang, K.; Guo, Y.; Xie, R.; Li, S. Currentstatus of maize mechanical grain harvesting and its relationship with grain moisture content. Sci Agric. Sin. 2017, 50, 2036-2043.

16. Tang, F.; Feng, J.; Yan, X.; Yang, W.; Shan, H. The effect of detract of corn into the silo from chute. J. Chinese Cereals Oils Assoc. 2015, 30, 98-101.

17. Cheng, X.D.; Feng, J.C.; Yan, X.J.; Huang, Z.B. Experimental study on structure damage of corn grain after collision. Grain Storage 2014, 43, 19-22.

18. Xue, J.; Li, L.L.; Zhang, W.X.; Wang, Q.; Xie, R.Z.; Wang, K.R.; Ming, B.; Hou, P.; Li, S.K. Maize cob mechanical strength and its influence on kernel broken rate. Sci. Agric. Sin. 2018, 51, 1868-1877.

19. Shah, D.U.; Reynolds, T.P.; Ramage, M.H.; Raines, C. The strength of plants: Theory and experimental methods to measure the mechanical properties of stems. J. Exp. Bot. 2016, 68, 4497-4516. [CrossRef] [PubMed]

20. Robertson, D.; Smith, S.; Gardunia, B.; Cook, D. An improved method for accurate phenotyping of corn stalk strength. Crop Sci. 2014, 54, 2038-2044. [CrossRef]

21. Verma, V.; Worland, A.; Savers, E.; Fish, L.; Caligari, P.; Snape, J. Identification and characterization of quantitative trait loci related to lodging resistance and associated traits in bread wheat. Plant Breed. 2005, 124, 234-241. [CrossRef]

22. Ma, Q.H. The expression of caffeic acid 3-O-methyltransferase in two wheat genotypes differing in lodging resistance. J. Exp. Bot. 2009, 60, 2763-2771. [CrossRef]

23. Niklas, K.J. Influence of tissue density-specific mechanical properties on the scaling of plant height. Ann. Bot. 1993, 72, 173-179. [CrossRef]

24. Gou, L.; Zhao, M.; Huang, J.J.; Zhang, B.; Li, T.; Sun, R. Bending mechanical properties of stalk and lodging-resistance of maize. Acta Agron. Sin. 2008, 34, 653-661. [CrossRef]

25. Kamrana, M.; Ahmada, I.; Wang, H.; Wu, X.; Xu, J.; Liu, T.; Ding, R.; Han, Q. Mepiquat chloride application increases lodging resistance of maize by enhancing stem physical strength and lignin biosynthesis. Field Crop Res. 2018, 224, 148-159. [CrossRef]

26. Xue, J.; Gao, S.; Fan, Y.; Li, L.; Ming, B.; Wang, K.; Xie, R.; Hou, P.; Li, S. Traits of plant morphology, stalk mechanical strength, and biomass accumulation in the selection of lodging-resistant maize cultivars. Eur. J. Agron. 2020, 117, 126073. [CrossRef] 
27. Anazodo, U.G.N.; Wall, G.L.; Norris, E.R. Corn physical and mechanical properties as related to combine cylinder performance. Can. Agric. Eng. 1981, 23, 23-30.

28. Zhang, L.H.; Li, H.J.; Wang, Y.Z. Study on the dynamic of soluble sugar and starch in the silk and cob of corn. J. Maize Sci. 2005, 13, 64-67.

29. Ci, X.K.; Li, M.S.; Xu, J.S.; Lu, Z.Y.; Bai, P.F.; Ru, G.L.; Liang, X.L.; Zhang, D.G.; Li, X.H.; Bai, L.; et al. Trends of grain yield and plant traits in Chinese maize cultivars from the 1950s to the 2000s. Euphytica 2012, 185, 395-406. [CrossRef]

30. Ma, D.; Xie, R.; Liu, X.; Niu, X.; Hou, P.; Wang, K.; Lu, Y.; Li, S. Lodging-Related stalk characteristics of maize varieties in China since the 1950s. Crop Sci. 2014, 54, 2805-2814. [CrossRef]

31. Shah, A.N.; Tanveer, M.; Rehman, A.U.; Anjum, S.A.; Iqbal, J.; Ahmad, R. Lodging stress in cereal-effects and management: An overview. Environ. Sci. Pollut. Res. 2017, 24, 5222-5237. [CrossRef] [PubMed]

32. Beck, D.L.; Darrah, L.L.; Zuber, M.S. Effect of sink level on root and stalk quality in maize. Crop Sci. 1988, 28, 11-18. [CrossRef]

33. Jampatong, S.; Darrah, L.L.; Krause, G.F.; Barry, B.D. Effect of one- and two-eared selection on stalk strength and other characters in maize. Crop Sci. 2000, 40, 605-611. [CrossRef]

34. Gentinetta, E.; Ceppi, D.; Lepori, C.; Perico, G.; Motto, M.; Salamini, F. A major gene for delayed senescence in maize. Pattern of photosynthates accumulation and inheritance. Plant Breed. 1986, 97, 193-203. [CrossRef]

35. Kosgey, J.R.; Moot, D.J.; Fletcher, A.L.; McKenzie, B.A. Dry matter accumulation and post-silking N economy of 'stay-green' maize (Zea mays L.) hybrids. Eur. J. Agron. 2013, 51, 43-52. [CrossRef]

36. Belicuas, P.R.; Aguiar, A.M.; Vieira Bento, D.A.; Maxwell Camara, T.M.; de Souza Junior, C.L. Inheritance of the stay-green trait in tropical maize. Euphytica 2014, 198, 163-173. [CrossRef]

37. Guo, Q.C.; Bai, G.H.; Liu, H.Q.; Wu, P.H.; Dou, B.D. Study on maize breeding in Huanghuaihai region. Bulletin Agri. Sci. Technol. 2015, 9, 7-11.

Publisher's Note: MDPI stays neutral with regard to jurisdictional claims in published maps and institutional affiliations.

(C) 2020 by the authors. Licensee MDPI, Basel, Switzerland. This article is an open access article distributed under the terms and conditions of the Creative Commons Attribution (CC BY) license (http://creativecommons.org/licenses/by/4.0/). 